\title{
PANDEMI COVID-19 DAN KEARIFAN LOKAL: PENYULUHAN BUDIDAYA TANAMAN SAMBUNG NYAWA (GYNURA PROCUMBENS) DI DUSUN JOMBLANG, TEGALTIRTO, BERBAH, SLEMAN, DAERAH ISTIMEWA YOGYAKARTA
}

\author{
${ }^{1}$ Ratnawati Yuni Suryandari, ${ }^{2}$ Ken Martina Kasikoen, ${ }^{3}$ Elsa Martini, ${ }^{4}$ Ario Kurnianto \\ ${ }^{1234}$ Fakultas Teknik, Universitas Esa Unggul, Jl. Arjuna Utara No.9, RT.1/RW.2, Duri Kepa, Kec. Kb. Jeruk, \\ Kota Jakarta Barat, Daerah Khusus Ibukota Jakarta 11510 \\ Email: ratnawatiys@esaunggul.ac.id
}

\section{RINGKASAN}

Pandemi covid-19 sedang melanda Indonesia dan sebagian besar negara di dunia. Pada 18 Juli 2020, jumlah penduduk Kabupaten Sleman yang terpapar covid-19 sebanyak 147 orang, pasien sembuh sebanyak 121 orang dan 5 orang meninggal dunia karena covid-19. Dusun Jomblang merupakan salah satu dusun di Kabupaten Sleman, menurut data, belum ada warganya yang terpapar virus corona. Walaupun Dusun Jomblang merupakan zona hijau, tetapi masyarakat di dusun tersebut tetap waspada dengan tetap menjaga kesehatan dan menaati peraturan pemerintah terkait covid-19, seperti selalu cuci tangan dengan sabun, memakai masker jika keluar rumah, serta menjaga jarak dan menghindari kerumunan. Di masa pandemi covid-19 ini, peningkatan imunitas tubuh sangat diperlukan agar jangan sampai terkena penyakit dan terpapar virus corona. Salah satu usaha untuk meningkatkan imunitas tubuh adalah dengan memanfaatkan kearifan lokal yaitu mengkonsumsi tanaman herbal yang dapat tumbuh dengan mudah di sekitar lingkungan kampung. Tanaman Sambung Nyawa atau daun Dewa (gynura procumbens) merupakan salah satu jenis tanaman herbal yang banyak khasiatnya, tetapi masih sedikit sekali masyarakat di Dusun Jomblang yang mengetahuinya dan menanamnya. Oleh karena itu, penyuluhan tentang khasiat dan budidaya tanaman Sambung Nyawa sangat diperlukan agar masyarakat di dusun tersebut dapat menanam tumbuhan Sambung Nyawa di pekarangan rumah dan dapat mengkonsumsi tanaman tersebut setiap hari. Dengan demikian, diharapkan agar imunitas tubuh masyarakat Dusun Jombang meningkat, selalu sehat, dan terhindar dari paparan virus corona.

\section{Kata kunci: Pandemi Covid-19; Kearifan Lokal; Budidaya; Tanaman Sambung Nyawa; Kesehatan}

\section{A. Latar Belakang}

Pandemi covid-19 sedang melanda Indonesia dan sebagian besar negara di dunia. Pada 18 Juli 2020, jumlah penduduk Indonesia yang terpapar covid-19 sebanyak 84,882 
orang dengan pasien sembuh sebanyak 43,268 orang dan yang meninggal dunia sebanyak 4,016

orang (https://nasional.kompas.com/read/2020/07/18/16014421/update-18-juli-bertambah1434-pasien-sembuh-dari-covid-19-kini-sebanyak). Untuk Kabupaten Sleman sendiri, pada tanggal yang sama, tercatat sebanyak 147 orang terpapar virus corona, pasien sembuh sebanyak 121 orang dan yang meninggal dunia sebanyak 5 orang (https://corona.jogjaprov.go.id/data-statistik). Dusun Jomblang, merupakan salah satu dusun di desa Tegaltirto, Berbah, Kabupaten Sleman. Sebagian besar penduduk Dusun Jomblang adalah petani. Berdasarkan data dari Gugus Tugas covid-19 Daerah Istimewa Yogyakarta 18 Juli 2020, masyarakat Dusun Jomblang belum ada yang terpapar virus corona. Walaupun dusun ini merupakan zona hijau, tetapi masyarakatnya tetap waspada dengan tetap menjaga kesehatan badan dan menaati peraturan pemerintah terkait covid19, seperti selalu cuci tangan dengan sabun, memakai masker jika keluar rumah, serta menjaga jarak dan menghindari kerumunan.

Di masa pandemi covid-19 ini, peningkatan imunitas tubuh sangat diperlukan agar jangan sampai sakit dan terpapar virus corona. Salah satu usaha untuk meningkatkan imunitas tubuh adalah dengan memanfaatkan kearifan lokal yaitu dengan cara mengkonsumsi tanaman herbal yang bisa didapatkan dengan mudah di sekitar lingkungan kita. Menurut Godbyah (2003), kearifan lokal merupakan produk budaya masa lalu yang patut secara terus-menerus dijadikan pegangan hidup. Meskipun bernilai lokal tetapi nilai yang terkandung di dalamnya dianggap sangat universal. Tanaman herbal Indonesia sudah lama dianggap sebagai pengobatan alternatif yang mumpuni. Bahkan sebagian besar sudah digunakan sebagai obat yang diakui dunia kedokteran.

Salah satu tanaman herbal yang banyak khasiatnya, tetapi masih banyak dari masyarakat Dusun Jomblang yang belum tahu manfaatnya yaitu tanaman Sambung Nyawa atau daun Dewa (Gynura Procumbens). Tanaman ini merupakan salah satu jenis tanaman asli Indonesia yang sudah lama digunakan oleh masyarakat untuk lalapan dan mengobati berbagai penyakit. Sambung Nyawa banyak terdapat di Pulau Jawa dan Sumatra, sebagian tumbuh liar di Pulau Bali (Wijayanti, 2012). Untuk menemukan 


\section{B. Metode Pelaksanaan}

Penyuluhan tentang manfaat dan budidaya tanaman Sambung Nyawa berlokasi di RW 28 Dusun Jomblang, Tegaltirto, Berbah, Sleman, Daerah Istimewa Yogyakarta. Waktu penyuluhan pada hari Minggu tanggal 19 Juli 2020 bertempat di halaman rumah salah satu warga. Peserta yang terlibat dalam penyuluhan ini sebanyak 20 orang warga masyarakat Dusun Jomblang.

Penyuluhan dilaksanakan dengan menggunakan protokol kesehatan. Peserta yang mengikuti penyuluhan diwajibkan memakai masker. Ketika akan memasuki kawasan penyuluhan, peserta mencuci tangan dengan sabun terlebih dahulu. Pada saat penyuluhan berlangsung, jarak antar para peserta sekitar $1-2$ meter.

Pada sesi pertama, penyuluh menjelaskan tentang tanaman Sambung Nyawa secara umum, kemudian dilanjutkan penjelasan tentang khasiat tanaman Sambung Nyawa dan cara mengkonsumsinya. Biasanya Sambung Nyawa dikonsumsi dengan cara dimakan begitu saja sebagai lalapan, tetapi jika ingin mengobati penyakit tertentu, maka daun atau batang Sambung Nyawa ini dapat dicampur dengan tanaman herbal yang lain.

Sesi kedua, penyuluhan tentang pembudidayaan tanaman Sambung Nyawa. Penyuluh mempraktekkan secara langsung cara-cara mengembangbiakkan tanaman ini. Peserta terlibat secara aktif mendengarkan, melihat dan bertanya tentang khasiat dan cara pengembangbiakan tanaman ini.

Setelah para peserta mengetahui manfaat tanaman Sambung Nyawa dan cara pembudidayaannya, maka sesi penyuluhan selanjutnya adalah pemberian satu pot tanaman Sambung Nyawa kepada para peserta untuk dibawa pulang ke rumah. Tanaman tersebut dapat mereka rawat dan jika daunnya sudah lebat dapat mereka konsumsi. Mereka juga dapat membudidayakan tanaman Sambung Nyawa agar tidak kehabisan daunnya jika harus dikonsumsi setiap hari oleh seluruh keluarga mereka.

\section{Hasil dan Pembahasan}

Pengabdian masyarakat tentang penyuluhan budidaya tanaman Sambung Nyawa ini dilaksanakan pada hari Minggu tanggal 19 Juli 2020 di RW 28 Dusun Jomblang, dengan 


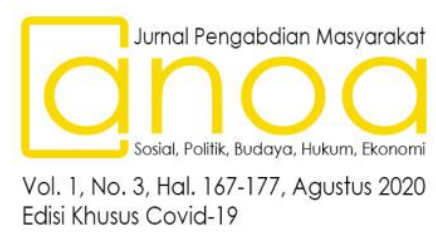

(https://manado.tribunnews.com/2020/02/12/6-manfaat-daun-sambung-nyawa-bisasembuhkan-penyakit-hati-sampai-diabetes?page $=4$.;

https://www.sehatq.com/artikel/manfaat-daun-sambung-nyawa-berdasarkanpenelitian-sudah-siap-mencoba).

b. Menurunkan tekanan darah

Tekanan darah tinggi atau hipertensi merupakan salah satu penyebab utama penyakit jantung, termasuk penyakit jantung koroner dan stroke. Daun Sambung Nyawa sangat berkhasiat dalam menurunkan tekanan darah tinggi karena memiliki sifat hipotensi yang berfungsi untuk menurunkan tekanan darah. Cara mengkonsumsi daun herbal ini bisa dibuat herbal, jus, atau dikonsumsi langsung dengan menu makanan. Banyak pasien hipertensi terpaksa meminum obat seumur hidup untuk menstabilkan tekanan darahnya. Penggunaan obat kimia jangka panjang mempunyai efek samping yang sangat berbahaya. Jadi, alternatif terbaik adalah mengonsumsi daun Sambung Nyawa.

c. Mengobati diabetes

Daun Sambung Nyawa memiliki sifat antihiperglikemik (obat diabetes). Salah satu temuan dari hewan uji menunjukkan bahwa manfaat daun Sambung Nyawa dapat menurunkan kadar gula darah dan menjaga kadar glukosa dalam darah, pada tikus yang mengalami diabetes. Cara mengonsumsi daun Sambung Nyawa sangat mudah yaitu daun ini dikonsumsi sebagai sayuran segar sebanyak 7 lembar daun. Lakukan ini sebelum makan sehingga dapat digunakan sebagai lalapan saat sarapan dan malam hari.

d. Menurunkan kolesterol

Daun Sambung Nyawa dapat digunakan untuk mengobati kolesterol dengan membuang kolesterol jahat dari dalam tubuh. Cara mengonsumsinya sangat mudah, cukup mengonsumsi 3 lembar daun herbal ini setiap hari.

e. Mengobati infertilitas

Infertilitas sebenarnya merupakan salah satu komplikasi diabetes. Untuk menanganinya, daun Sambung Nyawa kerap menjadi pilihan. Daun ini terbukti dapat meningkatkan jumlah sperma, pergerakan sperma, dan mengurangi persentasi kematian 


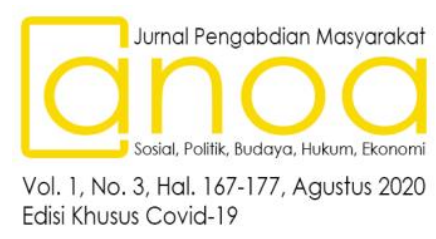

sel sperma, pada hewan uji yang mengalami diabetes. Selain itu juga, daun sambung nyawa memiliki efek afrodisiak (pembangkit gairah seksual) pada hewan uji yang sama. f. Mencegah malaria

Daun Sambung Nyawa mempunyai efek antimikroba. Oleh karena itu, daun Sambung Nyawa dipercaya dapat melawan berbagai parasit yang menyebabkan penyakit malaria, yaitu Plasmodium falciparum dan Plasmodium berghei.

g. Menjaga kesehatan otak

Menurut Wijayanti (2018), daun Sambung Nyawa mengandung antioksidan, seperti flavonoid, saponin, tanin, dan terpenoid. Flavonoid dikenal sebagai antioksidan yang dapat menurunkan resiko kanker, penyakit jantung, asma, hingga stroke. Antioksidan yang satu ini juga diklaim dapat menjaga kesehatan otak. Saponin dapat membantu tubuh mencegah kanker, menurunkan kadar kolesterol, dan menjaga kesehatan organ hati. Tanin memiliki kemampuan untuk mempercepat pembekuan darah, dan mengurangi tekanan darah. Selain itu, terpenoid dapat membantu tubuh mencegah beberapa penyakit, seperti kanker.

h. Mengobati sinusitis

Sinusitis merupakan penyakit yang disebabkan oleh radang dinding sinus. Gejalanya khas dan mudah dikenali dalam bentuk pilek terus menerus tanpa disertai flu, suaranya berubah, rasa sakit di daerah wajah. Sinusitis dapat disembuhkan dengan secara rutin mengonsumsi 7 lembar daun Sambung Nyawa yang diolah menjadi jus.

i. Mempercepat proses penyembuhan luka

Daun Sambung Nyawa sering digunakan untuk mengobati peradangan di dalam dunia medis Thailand. Pada saat ekstrak etanol daun Sambung Nyawa digunakan pada hewan uji yang sedang terluka, proses penyembuhan lukanya meningkat dan ukuran luka juga berkurang.

Selain beberapa manfaat daun Sambung Nyawa di atas, berbagai penelitian juga telah menunjukkan bahwa daun ini dapat mengobati penyakit ginjal, mencairkan pembekuan darah, menghentikan perdarahan, membersihkan tubuh dari racun, batuk, radang kerongkongan, hingga mengatasi demam (Wijayanti, 2012; 
2. Batang yang sudah dipotong menjadi beberapa bagian dimasukkan ke dalam tempat yang sudah diisi dengan air. Letakkan di tempat yang tidak terkena sinar matahari secara langsung. Tunggu 7-15 hari, akar akan tumbuh di bagian bawah batang yang dipotong-potong tersebut.

3. Setelah akar sudah tumbuh agak lebat di bagian bawah batang, pindahkan bibit tanaman Sambung Nyawa tersebut ke dalam pot yang sudah diisi media tanam. Letakkan pot tersebut di lokasi yang agak rindang, terhindar dari panas matahari langsung, dan disiram setiap hari agar tanaman Sambung Nyawa cepat tumbuh dan berdaun lebat.

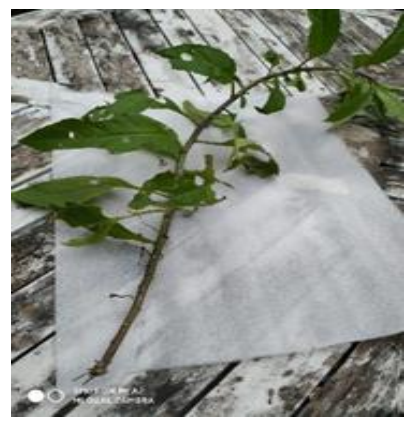

Gambar 1.

Batang Sambung Nyawa yang akan dibudidayakan

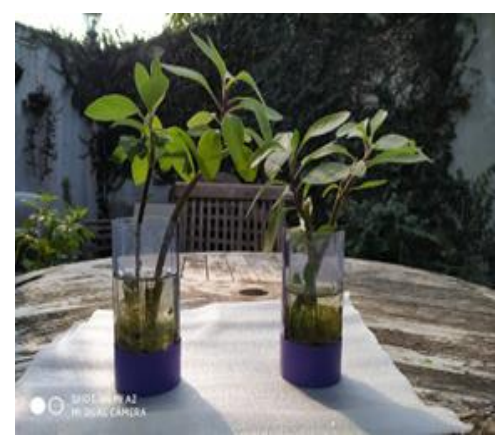

Gambar 4. Akar Sambung Nyawa akan tumbuh dalam waktu 7 - 15 hari

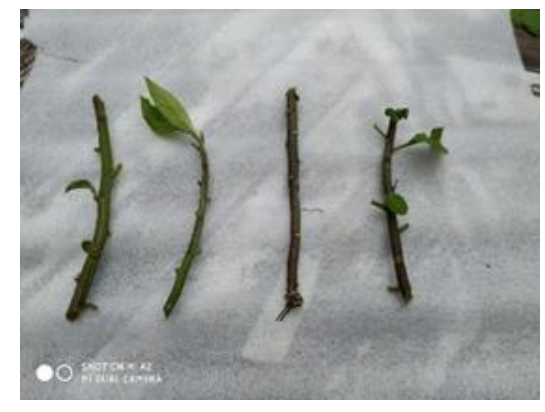

Gambar 2.

Batang Sambung Nyawa dipotong miring menjadi beberapa (15-20 $\mathrm{cm}$ ) dan dipotong daunnya

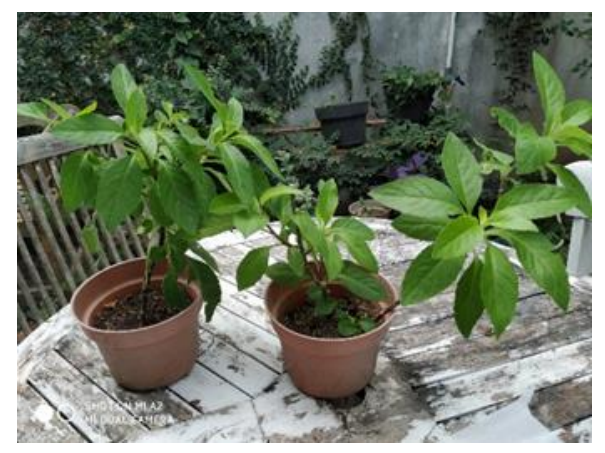

Gambar 5.

Bibit Sambung Nyawa dipindahkan ke dalam pot, disiram setiap hari

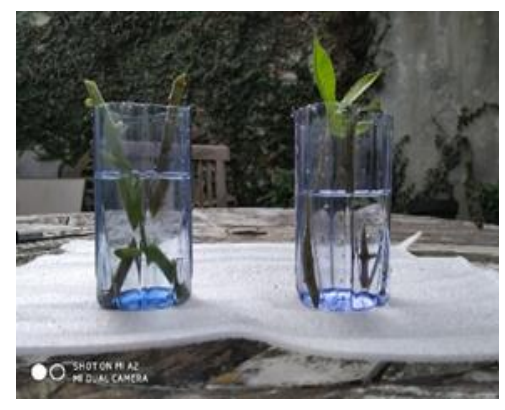

Gambar 3.

Batang Sambung Nyawa dimasukkan ke dalam pot plastik yang sudah diisi air

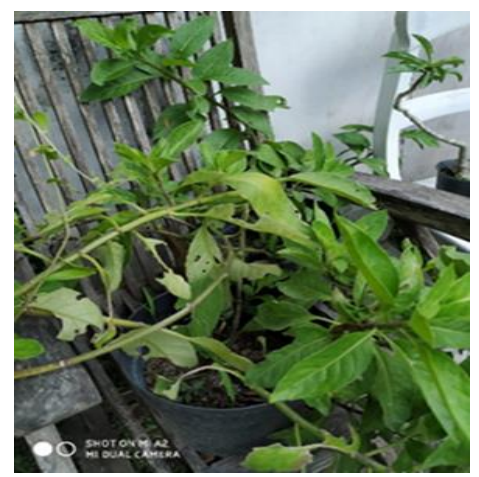

Gambar 6.

Tanaman Sambung Nyawa yang sudah dewasa 


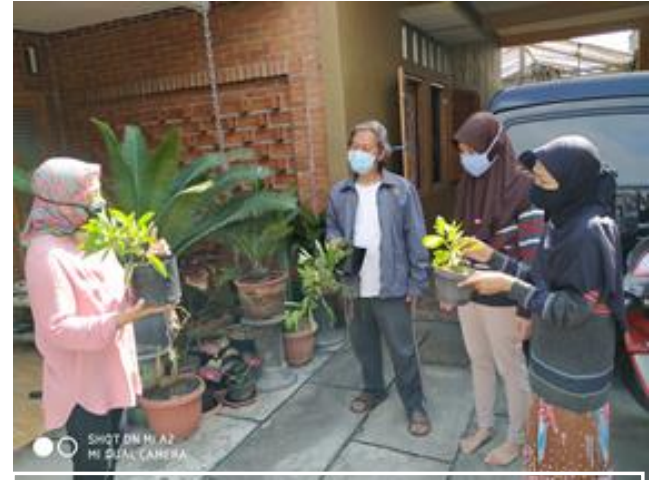

Gambar 7.

Penyerahan tanaman Sambung Nyawa kepada peserta penyuluhan

Sesi ketiga atau sesi terakhir, sebelum penyuluhan ditutup, para peserta diberi satu pot tanaman Sambung Nyawa (Gambar 7.) Diharapkan tanaman tersebut dapat dipelihara dengan baik. Jika tanaman tersebut sudah tumbuh lebat daunnya, maka daun tersebut dapat dikonsumsi setiap hari oleh para peserta penyuluhan. Tubuh menjadi sehat dan tidak mudah terserang penyakit.

Para peserta juga diharapkan dapat menyebarkan informasi tentang manfaat tanaman Sambung Nyawa dan memberikan bibitnya kepada warga yang tidak ikut penyuluhan, dengan harapan agar seluruh warga Dusun Jomblang dapat merasakan manfaat tanaman Sambung Nyawa.

\section{Kesimpulan}

Pengabdian masyarakat dalam bentuk penyuluhan ini dapat meningkatkan pengetahuan masyarakat di Dusun Jomblang tentang khasiat dan budidaya tanaman Sambung Nyawa. Manfaat daun Sambung Nyawa antara lain mengobati penyakit kanker, jantung, kolesterol, hipertensi, diabetes dan lain-lain. Sedangkan budidaya tanaman ini dengan menggunakan stek batang.

Setelah mengikuti penyuluhan ini, masyarakat semakin mengetahui manfaat tanaman Sambung Nyawa dan mereka dapat membudidayakan sendiri tanaman tersebut. Untuk selanjutnya masyarakat dapat mengonsumsi daun Sambung Nyawa setiap hari sebagai lalapan. Dengan demikian, masyarakat menjadi sehat, imunitas tubuh meningkat dan harapannya terhindar dari virus corona.

\section{DAFTAR PUSTAKA}

Gobyah, I Ketut. (2003). Berpijak pada Kearifan Lokal. Bali Post Online 17 September 2003. [Online] Available: http://www.balipost.co.id/BALIPOSTCETAK/2003/ 9/17/bd3.htm. (diunduh 24/7/2020) 
Pujiasmanto, B. (2016). Strategi Pengembangan Budidaya Tumbuhan Obat dalam Menunjang Pertanian Berkelanjutan. Diunduh 24 Juli 2020 dari https://library.uns.ac.id/strategi-pengembangan-budidayatumbuhan-obat-dalammenunjang-pertanian-berkelanjutan/.

Sakinah, D.G., Putra, E.T.S., Rohlan Rogomulyo, R. (2018). Produksi dan Kadar Flavonoid Daun Sambung Nyawa (Gynura procumbens (Lour.) Merr.) pada Tiga Fase Agroforestri Production and Flavonoid Contents of Sambung Nyawa Leaves (Gynura procumbens (Lour.) Merr.) in Three Stages of Agroforestry. Vegetalika, 7 (3), 1-15.

Wijayanti, Rachma. (2012). Budidaya Sambung Nyawa [Gynura Procumbens (Lourr.) (Merr.)] dan khasiatnya di PT Indmira Yogyakarta. Tugas Akhir. Fakultas Pertanian. Universitas Sebelas Maret Surakarta.

https://corona.jogjaprov.go.id/data-statistik (diunduh 19/7/2020).

https://nasional.kompas.com/read/2020/07/18/16014421/update-18-juli-bertambah1434-pasien-sembuh-dari-covid-19-kini-sebanyak (diunduh 19/7/2020). https://www.fimela.com/beauty-health/read/3831192/budidaya-sambung-nyawa (diunduh 19/7/2020).

https://manado.tribunnews.com/2020/02/12/6-manfaat-daun-sambung-nyawa-bisasembuhkan-penyakit-hati-sampai-diabetes?page=4. (diunduh 20/7/2020).

https://www.sehatq.com/artikel/manfaat-daun-sambung-nyawa-berdasarkan-penelitiansudah-siap-mencoba). (diunduh 20/7/2020).

https://kumparan.com/kumparannews/85-kematian-akibat-corona-di-ri-karena-pasienpunya-penyakit-bawaan-1thpsfIpL60 (diunduh 31/7/2020). 